\title{
Novologues Containing a Benzamide Side Chain Manifest Anti- proliferative Activity Against Two Breast Cancer Cell Lines
}

\author{
Huiping Zhao, Mercy Anyika, Antwan Girgis, and Brian S. J. Blagg ${ }^{*}$ \\ Department of Medicinal Chemistry, 1251 Wescoe Hall Drive, Malott 4070, The University of \\ Kansas, Lawrence, Kansas 66045-7563
}

The heat shock protein 90 (Hsp90) folding machinery is essential for the maturation of nascent polypeptides into their biologically active three-dimensional-structures and for the rematuration/clearance of misfolded proteins that form under cellular stress. ${ }^{1-3}$ As a prosurvival chaperone, Hsp90 overexpression is commonly observed in transformed cells, which is required to sustain the hostile tumor micro-environment associated with nutrient deprivation and hypoxia. Pharmacological inhibition of Hsp90 has been shown to induce the degradation of oncogenic proteins associated with all six hallmarks of cancer that rely upon Hsp90. ${ }^{4-8}$ Consequently, Hsp90 represents a highly sought after target for the treatment of cancer. In fact, 17 small molecules that bind competitively to the N-terminal ATP-binding pocket are under clinical evaluation against various cancers. ${ }^{9,10}$ However, heat shock factor 1 (HSF-1), the master regulator of the pro-survival heat shock response also binds Hsp90. Ultimately, Hsp90 N-terminal inhibition results in HSF-1 release, and upon phosphorylation, trimerizes and translocates to the nucleus wherein it binds the heat shock elements to activate the pro-survival, heat shock response (HSR). The HSR serves to expand the cellular buffering capacity and to assist in the maturation of mutated and oncogenic substrates. ${ }^{11}$ This concomitant heat shock response is detrimental to the treatment of cancer and may lead to drug resistance and tumor metastasis. ${ }^{12}$ Recent studies have demonstrated that allosteric modulation of the Hsp90 C-terminus can separate the pro-survival heat shock response from pro-apoptotic, client protein degradation. ${ }^{13-20}$ Two classes of small molecules derived from novobiocin 1, (Figure 1) the first identified Hsp90 C-terminal inhibitor, were discovered via the structure-activity relationship studies. KU-32 (2), which lacks a 4-hydroxyl, the 3'carbamate, and contains an acetamide in lieu of a prenylated benzamide, represents a lead compound that induces the heat shock response at concentrations much lower than that needed for client protein degradation. ${ }^{2,21}$ Consequently, this class of analogues has been evaluated as neuroprotective agents to refold protein aggregates. ${ }^{22-24}$ In contrast, KU-174 (3) contains a biarylamide side chain in lieu of the acetamide, and induces Hsp90 client protein degradation without induction of the heat shock response. ${ }^{25-26}$ Therefore, this class

() 2014 Elsevier Ltd. All rights reserved.

*Author to whom correspondence should be addressed. Phone: (785) 864-2288. Fax: (785) 864-5326. bblagg@ku.edu.

Publisher's Disclaimer: This is a PDF file of an unedited manuscript that has been accepted for publication. As a service to our customers we are providing this early version of the manuscript. The manuscript will undergo copyediting, typesetting, and review of the resulting proof before it is published in its final citable form. Please note that during the production process errors may be discovered which could affect the content, and all legal disclaimers that apply to the journal pertain. 
of novobiocin analogues manifests optimal properties for the treatment of cancer, as no HSR is observed with such compounds.

Recently, a second generation of novologues that contains a scaffold that mimics KU-32 was identified, and biological evaluation against primary sensory neurons showed these molecules to possess enhanced neuroprotective properties. ${ }^{27}$ Novologue 4 contains a 3trifluoromethylphenyl ring in lieu of the coumarin lactone present in novobiocin and incorporates the acetamide onto the flexible ethylene linker to maintain hydrogen-bonding interactions with the Hsp90 C-terminal binding pocket. As shown during the discovery and development of novobiocin-based Hsp90 C-terminal inhibitors, restoration of the benzamide side chain onto KU-32 transforms the molecule from manifesting neuroprotective activity into one that serves as an anti-cancer agent. Therefore, we hypothesized that replacement of the acetamide present in novologue $\mathbf{4}$ with a biarylamide should also transform this novologue into an anti-proliferative agent (5a).

As shown in Scheme 1, retrosynthesis of compound 5a (and related analogues) was envisioned for construction via noviosylation of phenol $\mathbf{7}$ by activated noviose carbonate, $\boldsymbol{6}$. Intermediate $\mathbf{7}$ could be assembled via an amide coupling reaction between amine $\mathbf{8}$ and acid chloride $\mathbf{9}$, followed by hydrogenolysis. As reported previously, ${ }^{27}$ the synthesis of amine $\mathbf{8}$ could be achieved from 2,4-dihydroxybenaldehyde through phenol protection, Suzuki coupling, a Henry reaction, and reduction of the corresponding $\alpha, \beta$-unsaturated nitro styrene.

Synthesis of these novologues commenced via selective phenol protection of 2,4dihydroxybenaldehyde (10) with benzyl bromide. The resulting benzyl ether was converted to trifluoromethanesulfonate $\mathbf{1 1}$, in the presence of trifluoromethanesulfonic anhydride and triethylamine. Subsequent Suzuki coupling with commercially available aryl boronic acids (phenyl, $m-\mathrm{CF}_{3}, m-\mathrm{Cl}, m-\mathrm{F}$ and $m$-OMe) was employed to generate the respective biaryl ring systems, 12a-e. These boronic acids were selected based on prior studies that suggested the inclusion of electronegative substituents at the meta-position of the B-ring exhibit favorable interactions with Lys539 in the Hsp90 C-terminal binding pocket. ${ }^{27}$

Benzaldehydes 12a-e were subjected to a Henry reaction to afford the corresponding nitrostyrenes, 13a-e. Subsequent lithium aluminum hydride reduction of the nitrostyrenes to the corresponding amines, followed by acylation with benzoyl chlorides 9a-e gave the benzyl ether containing benzamides, which upon hydrogenolysis produced phenols $\mathbf{7 a - i}$.

Preparation of the novologues required noviosylation of phenols 7a-e, which occurred upon treatment with the trichloroacetimidate of noviose carbonate $\mathbf{6}$ in the presence of catalytic boron trifluoride etherate, followed by solvolysis of the cyclic carbonate with methanolic ammonia to generate the desired products, 5a-e, in good yields.

In addition, novologues 14a-i were synthesized to investigate prior observations that suggested the replacement of noviose with amines could further increase inhibitory activity and solubility. ${ }^{28-31}$ Therefore, Mitsunobu etherification of phenols 7a-i with 1-methyl-4hydroxypiperidine was performed to yield the amino containing novologues, 14a-i. 
Upon construction of the library, these novologues were evaluated for antiproliferative activity against two breast cancer cell lines: SKBr3 (estrogen receptor negative, HER2 overexpressing breast cancer cells) and MCF-7 (estrogen receptor positive breast cancer cells). As shown in Table 1, the novologues manifested anti-proliferative activity against both breast cancer cell lines. Novologues containing a piperidine ring were shown to exhibit greater activity than their noviose containing counterparts (14a-e vs 5a-e), which is consistent with prior studies on novobiocin. ${ }^{28}$ Although substitutions on the benzamide side chain were beneficial to anti-proliferative activity, 4-Cl (5e) and 4-methoxy (5c) were better than 4-t-butyl (5d) for the compounds containing noviose. However, compounds containing the piperidine ring manifested better activity when 4-t-butyl (15c) or 4-Cl (15d) were present, compared to the 4-methoxy derivative (15b). Substitutions on the B ring did not produce significant differences in anti-proliferative activity, however, as predicted, the inclusion of an electronegative atom $\left(\mathrm{F}, \mathrm{Cl}\right.$ and $\left.\mathrm{CF}_{3}\right)$ at the meta-position of the B-ring was most active. As hypothesized, all the novologues were more active than the parent, acetamide-containing, neuroprotective compound 4.

In order to gain further insight into this class of compounds, a comparison between the antiproliferative activities manifested by novobiocin-derived inhibitors and these novologues was performed. Although the benzamide side chain is attached to a freely rotating ethylene linker in novologues $\mathbf{5 a}$ and $\mathbf{1 4 a}$, they manifested similar activity to novobiocin derivatives 16 and 17, suggesting that this new scaffold can serve as a surrogate for the coumarin ring system. More importantly, the entropic penalty introduced by incorporation of the ethylene linker appears to be compensated by interactions provided by incorporation of the trifluorophenyl ring. Alternatively, the rigid coumarin ring system may not be optimal for binding interactions.

To confirm that Hsp90 inhibition was responsible for the observed anti-proliferative activities manifested by these novologues, Western blot analyses of several Hsp90 dependent client protein levels were examined in MCF-7 cell lysates treated with 14a. ${ }^{32}$ As shown in Figure 2, Her2, Raf-1 and p-Akt, all of which are well-validated Hsp90-dependent client proteins, were degraded in a concentration-dependent manner, while non-Hsp90dependent actin levels remained constant. In addition, Hsp90 levels remained unchanged, indicating that these novologues bind the Hsp90 C-terminus. ${ }^{33-36}$

In conclusion, a library of benzamide-containing novologues was designed, synthesized and evaluated against two breast cancer cell lines. Initial structure-activity relationships for the amide appendage were elucidated and novologue 14a was shown to exhibit lead-like activity. Western blot analyses demonstrated these compounds to manifest anti-proliferative activity through Hsp90 inhibition. Replacement of the acetamide side chain on the novologue scaffold with a benzamide side chain successfully transformed this class of neuroprotective agents into molecules that exhibit anti-proliferative activity. Further structure-activity relationship studies on this novologue scaffold are currently underway and will be reported in due course. 


\section{References and notes}

1. Blagg BSJ, Kerr TA. Medicinal Research Reviews. 2006; 26:310. [PubMed: 16385472]

2. Zhao H, Michaelis Mary L, Blagg Brian SJ. Adv Pharmacol. 2012; 64:1. [PubMed: 22840743]

3. Soti C, Nagy E, Giricz Z, Vigh L, Csermely P, Ferdinandy PBrit. J. Pharmacol. 2005; 146:769.

4. Hanahan D, Weinberg RA. Cell. 2011; 144:646. [PubMed: 21376230]

5. Bishop SC, Burlison JA, Blagg BSJ. Curr. Cancer Drug Targets. 2007; 7:369. [PubMed: 17979631]

6. Blagg BSJ, Kerr TD. Med. Res. Rev. 2006; 26:310. [PubMed: 16385472]

7. Hanahan D, Weinberg RA. Cell. 2000; 100:57. [PubMed: 10647931]

8. Zhang H, Burrows F. J. Mol. Med. 2004; 82:488. [PubMed: 15168026]

9. Neckers L, Workman P. Clinical Cancer Research. 2012; 18:64. [PubMed: 22215907]

10. Biamonte MA, Van de Water R, Arndt JW, Scannevin RH, Perret D, Lee W. J. Med. Chem. 2010; 53:3. [PubMed: 20055425]

11. Taipale M, Jarosz DF, Lindquist S. Nature Reviews Molecular Cell Biology. 2010; 11:515.

12. Whitesell L, Santagata S, Lin NU. Curr. Mol. Med. 2012; 12:1108. [PubMed: 22804235]

13. Zhao, Huiping; Blagg, BSJ. Inhibitors of Molecular Chaperones As Therapeutic Agents. Timothy, D.; Machajewski, GZ., editors. London: RSC Publishing; 2014. p. 259

14. Shelton SN, Shawgo ME, Matthews SB, Lu Y, Donnelly AC, Szabla K, Tanol M, Vielhauer GA, Rajewski RA, Matts RL, Blagg BSJ, Robertson JD. Mol. Pharmacol. 2009; 76:1314. [PubMed: 19741006]

15. Cohen Stephanie M, Mukerji R, Samadi Abbas K, Zhang X, Zhao H, Blagg Brian SJ, Cohen Mark S. Ann Surg Oncol. 2012; 19(Suppl 3):S483. [PubMed: 21837531]

16. Burlison JA, Avila C, Vielhauer G, Lubbers DJ, Holzbeierlein J, Blagg BSJ. J. Org. Chem. 2008; 73:2130. [PubMed: 18293999]

17. Burlison JA, Blagg BS. J. Org. Lett. 2006; 8:4855.

18. Burlison JA, Neckers L, Smith AB, Maxwell A, Blagg BSJ. J. Am. Chem. Soc. 2006; 128:15529. [PubMed: 17132020]

19. Donnelly A, Mays JR, Burlison JA, Nelson JT, Vielhauer G, Holzbeierlein J, Blagg BSJ. J. Org. Chem. 2008; 73:8901. [PubMed: 18939877]

20. Yu XM, Shen G, Neckers L, Blake H, Holzbeierlein J, Cronk B, Blagg BSJ. J. Am. Chem. Soc. 2005; 127:12778. [PubMed: 16159253]

21. Ansar S, Burlison JA, Hadden MK, Yu XM, Desino KE, Bean J, Neckers L, Audus KL, Michaelis ML, Blagg BSJ. Bioorganic \& Medicinal Chemistry Letters. 2007; 17:1984. [PubMed: 17276679]

22. Zhang L, Zhao H, Blagg BSJ, Dobrowsky RT. J. Proteome Res. 2012; 11:2581. [PubMed: 22413817]

23. Urban MJ, Pan P, Farmer KL, Zhao H, Blagg BSJ, Dobrowsky RT. Exp. Neurol. 2012; 235:388. [PubMed: 22465570]

24. Li C, Ma J, Zhao H, Blagg BSJ, Dobrowsky RT. ASN Neuro. 2012; 4:425.

25. Eskew JD, Sadikot T, Morales P, Duren A, Dunwiddie I, Swink M, Zhang XY, Hembruff S, A, Rajewski RA, Blagg BSJ, Manjarrez JR, Matts RL, Holzbeierlein JM, Vielhauer GA. Bmc Cancer. $2011 ; 11$

26. Peterson, Laura B.; Blagg, Brian SJ. Bioorganic \& Medicinal Chemistry Letters. 2010; 20:3957. [PubMed: 20570149]

27. Kusuma BR, Zhang L, Sundstrom T, Peterson LB, Dobrowsky RT, Blagg BSJ. Journal of Medicinal Chemistry. 2012; 55:5797. [PubMed: 22702513]

28. Zhao H, Donnelly AC, Kusuma BR, Brandt GE, Brown D, Rajewski RA, Vielhauer G, Holzbeierlein J, Cohen MS, Blagg BS. Journal of medicinal chemistry. 2011; 54:3839. [PubMed: 21553822]

29. Donnelly AC, Zhao HP, Kusuma BR, Blagg BSJ. Med. chem. comm. 2010; 1:165.

30. Zhao HP, Kusuma B, Blagg BSJ. Acs Medicinal Chemistry Letters. 2010; 1:311. [PubMed: 21904660] 
31. Zhao, Huiping; Blagg, Brian SJ. Bioorganic \& Medicinal Chemistry Letters. 2013; 23:552. [PubMed: 23234644]

32. MCF7 cells were grown to confluence and seeded at $0.4 \times 10^{6}$ cells $/$ well $/ 2 \mathrm{~mL}$. Cells were incubated for 24 hours and treated with varying concentrations of 14a in DMSO (0.25\% DMSO final concentration), or vehicle (DMSO) for 24 hours. Cells were harvested in cold PBS and lysed using MPER (Thermo Scientific) supplemented with protease and phosphatase inhibitors (Roche) according to manufacturer's directions. Lysates were clarified at $14,000 \mathrm{~g}$ for 15 minutes at $4^{\circ} \mathrm{C}$. Protein concentrations were determined using the Pierce BCA protein assay kit per the manufacturer's instructions. Equal amounts of protein $(5 \mu \mathrm{g})$ were electrophoresed under reducing conditions (10\% acrylamide gels), transferred to PVDF, and immunoblotted with the corresponding antibody. Membranes were incubated with an appropriate horseradish peroxidaselabeled secondary antibody, developed with a chemiluminescent substrate, and visualized.

33. Zhao H, Moroni E, Yan B, Colombo G, Blagg BS. ACS medicinal chemistry letters. 2012; 4:57. [PubMed: 23606927]

34. Zhao HP, Brandt GE, Galam L, Matts RL, Blagg BSJ. Bioorganic \& Medicinal Chemistry Letters. 2011; 21:2659. [PubMed: 21273068]

35. Zhao H, Yan B, Peterson LB, Blagg BS. ACS medicinal chemistry letters. 2012; 3:327. [PubMed: 23316269]

36. Tran P, Kim SA, Choi HS, Yoon JH, Ahn SG. Bmc Cancer. 2010; 10 


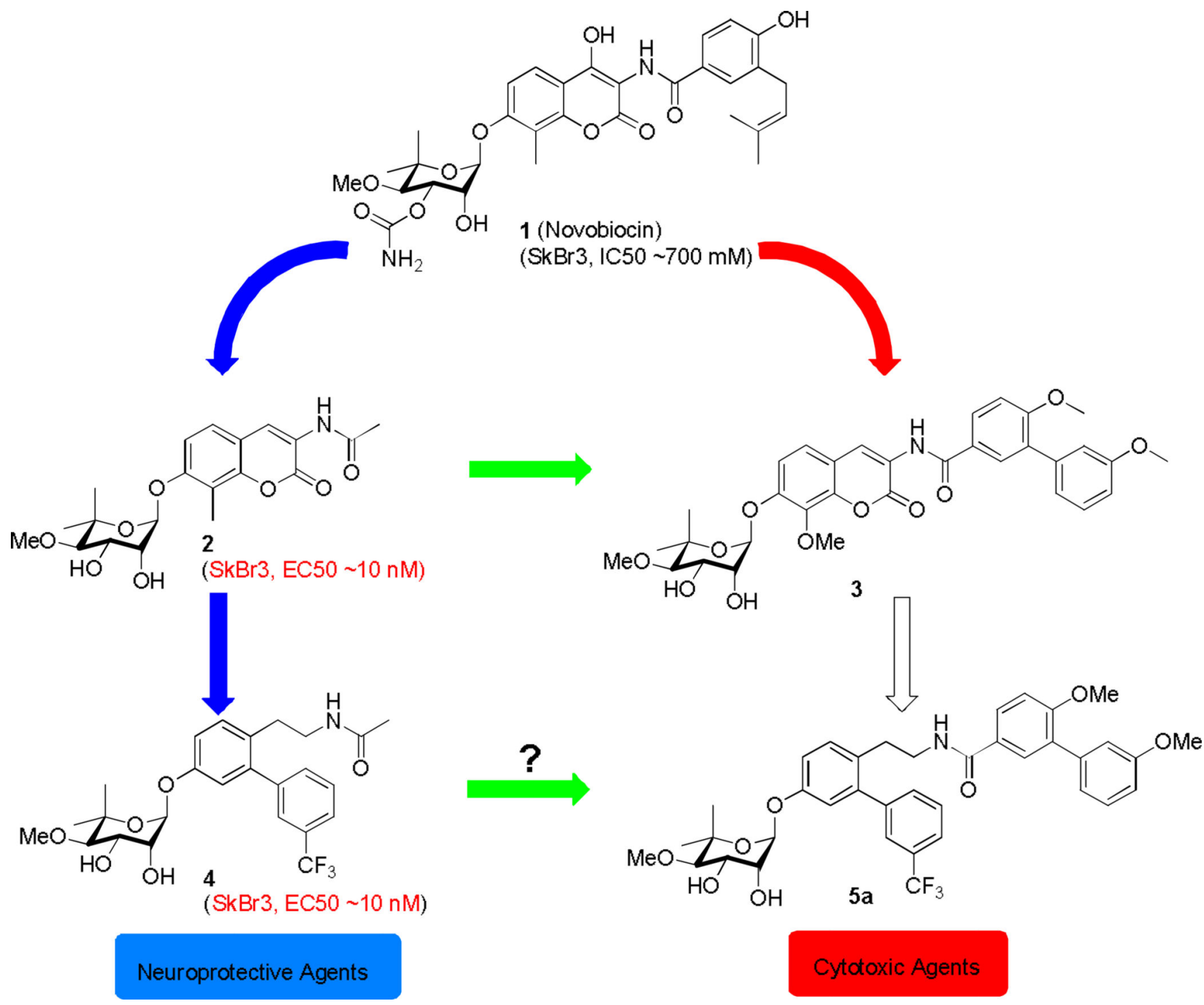

Figure 1.

Hypothesis for the design of cytotoxic novologues. 
10

50

10

25

G

D

\section{Her 2}

\section{Hsp90}

Raf-1

Akt

\section{Actin}
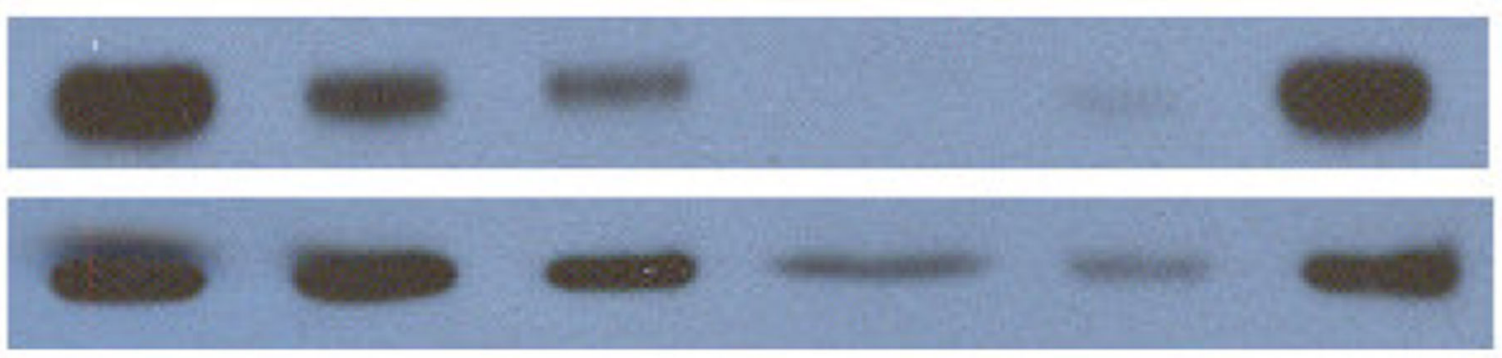

\section{Figure 2.}

Western blot analysis of Hsp90-dependent client proteins from MCF-7 breast cancer cell lysate upon treatment with 14a. Concentrations (in $\mu \mathrm{M}$ ) were indicated above each line. Geldanamycin $(\mathrm{G}, 0.5 \mu \mathrm{M})$ and dimethylsulfoxide $(\mathrm{D}, 100 \%)$ were employed as positive and negative controls. 


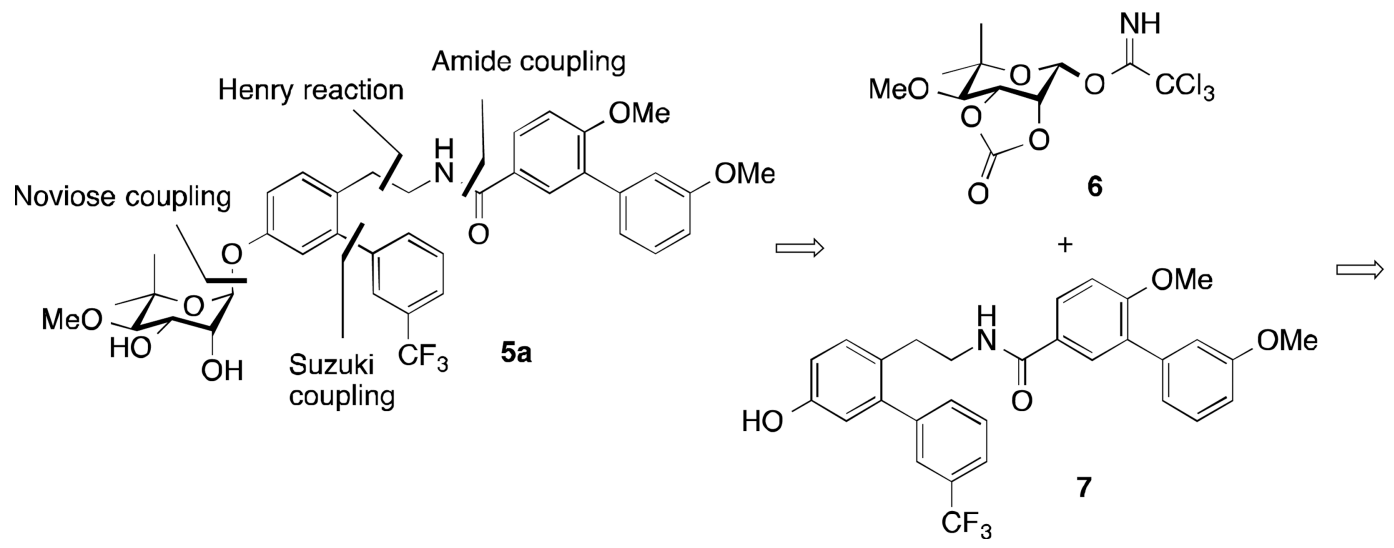<smiles>NCCc1ccc(OCc2ccccc2)cc1-c1cccc(C(F)(F)F)c1</smiles>

Scheme 1.

Retrosynthesis of cytotoxic novologues. 


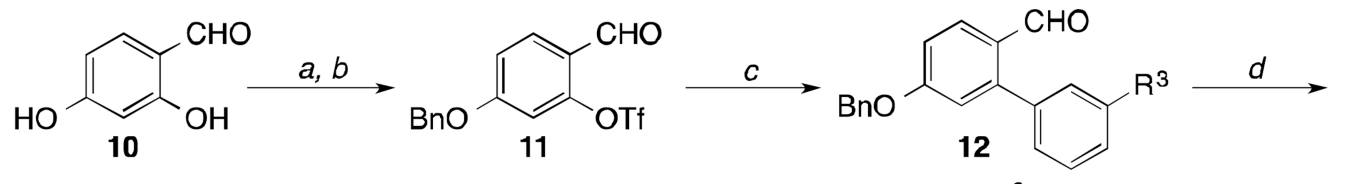

12a: $\mathrm{R}^{3}=\mathrm{CF}_{3}$

$12 \mathrm{~b}: \mathrm{R}^{3}=\mathrm{Cl}$

12c: $\mathrm{R}^{3}=\mathrm{F}$

$12 \mathrm{~d}: \mathrm{R}^{3}=\mathrm{OMe}$<smiles>[R7]c1cccc(-c2cc(O)ccc2CCNC(=O)c2ccc([R7])c([R])c2)c1</smiles>

13a: $\mathrm{R}^{3}=\mathrm{CF}_{3}$

$9 b: R^{1}=H, R^{2}=H$

$9 \mathrm{c}: \mathrm{R}^{1}=\mathrm{OMe}, \mathrm{R}^{2}=\mathrm{H}$

$13 c: R^{3}=F$

9d: $\mathrm{R}^{1}=\mathrm{t}-$ Butyl, $\mathrm{R}^{2}=\mathrm{H}$

$7 \mathrm{a}: \mathrm{R}^{1}=\mathrm{OMe}, \mathrm{R}^{2}=$ 3-methoxylphenyl

13d: $\mathrm{R}^{3}=\mathrm{OMe}$

9e: $\mathrm{R}^{1}=\mathrm{Cl}, \mathrm{R}^{2}=\mathrm{H}$

$7 \mathbf{b}: \mathrm{R}^{1}=\mathrm{H}, \mathrm{R}^{2}=\mathrm{H}$

13e: $\mathrm{R}^{3}=\mathrm{H}$

$7 \mathrm{c}: \mathrm{R}^{1}=\mathrm{OMe}, \mathrm{R}^{2}=\mathrm{H}$

7d: $R^{1}=\mathrm{t}-$ Butyl, $\mathrm{R}^{2}=\mathrm{H}$

7e: $\mathrm{R}^{1}=\mathrm{Cl}, \mathrm{R}^{2}=\mathrm{H}$

7f: $R^{1}=\mathrm{OMe}, \mathrm{R}^{2}=$ 3-methoxylphenyl

7g: $\mathrm{R}^{1}=\mathrm{OMe}, \mathrm{R}^{2}=3$-methoxylphenyl

7h: $\mathrm{R}^{1}=\mathrm{OMe}, \mathrm{R}^{2}=3$-methoxylphenyl

7i: $\mathrm{R}^{1}=\mathrm{OMe}, \mathrm{R}^{2}=3-$ methoxylphenyl

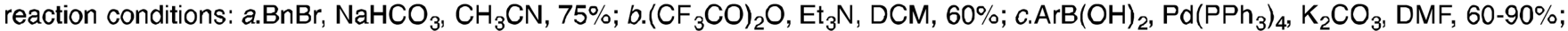
d. $\mathrm{CH}_{3} \mathrm{NO}_{2}, \mathrm{NH}_{4} \mathrm{OAc}, 90-98 \%$; e.LiAlH 4 , THF, 30 min, f.Et ${ }_{3} \mathrm{~N}$, DCM 61-75\% over 2 steps; $g . \mathrm{H}_{2}, \mathrm{Pd} / \mathrm{C}, \mathrm{MeOH}, 70-80 \%$.

Scheme 2.

Synthesis of phenol 7a-e. 


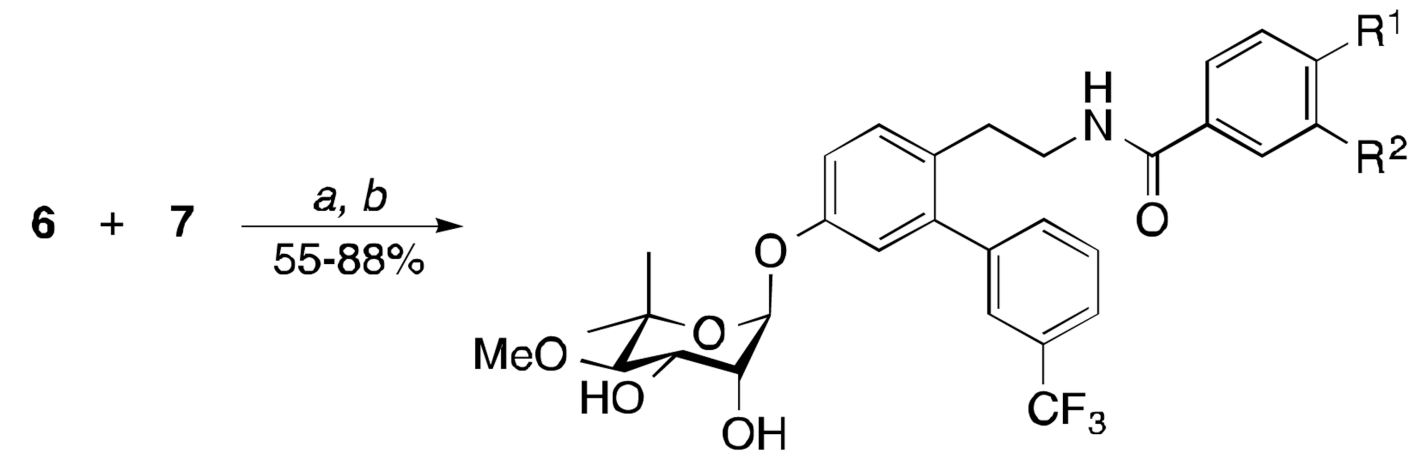

$5 a: R^{1}=O M e, R^{2}=3-$ methoxylphenyl

$5 b: R^{1}=H, R^{2}=H$

$5 c: R^{1}=O M e, R^{2}=H$

5d: $R^{1}=$ t-Butyl, $R^{2}=\mathrm{H}$

$5 \mathrm{e}: \mathrm{R}^{1}=\mathrm{Cl}, \mathrm{R}^{2}=\mathrm{H}$<smiles>[R8]c1cccc(-c2cc(OC3CCN(C)CC3)ccc2CCNC(=O)c2ccc([R7])c([R2])c2)c1</smiles>

14a: $R^{1}=$ OMe, $R^{2}=3$-methoxylphenyl, $R^{3}=C_{3}$

14b: $R^{1}=$ OMe, $R^{2}=3$-methoxylphenyl, $R^{3}=\mathrm{Cl}$

14c: $R^{1}=$ OMe, $R^{2}=3$-methoxylphenyl, $R^{3}=F$

14d: $R^{1}=$ OMe, $R^{2}=3$-methoxylphenyl, $R^{3}=$ OMe

14e: $R^{1}=$ OMe, $R^{2}=3$-methoxylphenyl, $R^{3}=H$

15a: $R^{1}=\mathrm{H}, \mathrm{R}^{2}=\mathrm{H}$

$15 b: R^{1}=O M e, R^{2}=H$

15c: $R^{1}=t-B u t y l, R^{2}=H$

15d: $\mathrm{R}^{1}=\mathrm{Cl}, \mathrm{R}^{2}=\mathrm{H}$

reaction conditions: a. $\mathrm{BF}_{3} \bullet \mathrm{Et}_{2} \mathrm{O}, \mathrm{DCM} ; b$. $\mathrm{Et}_{3} \mathrm{~N}, \mathrm{MeOH}, c . \mathrm{Ph}_{3} \mathrm{P}, \mathrm{DIAD}, \mathrm{THF}$.

Scheme 3.

Synthesis of cytotoxic novologues. 


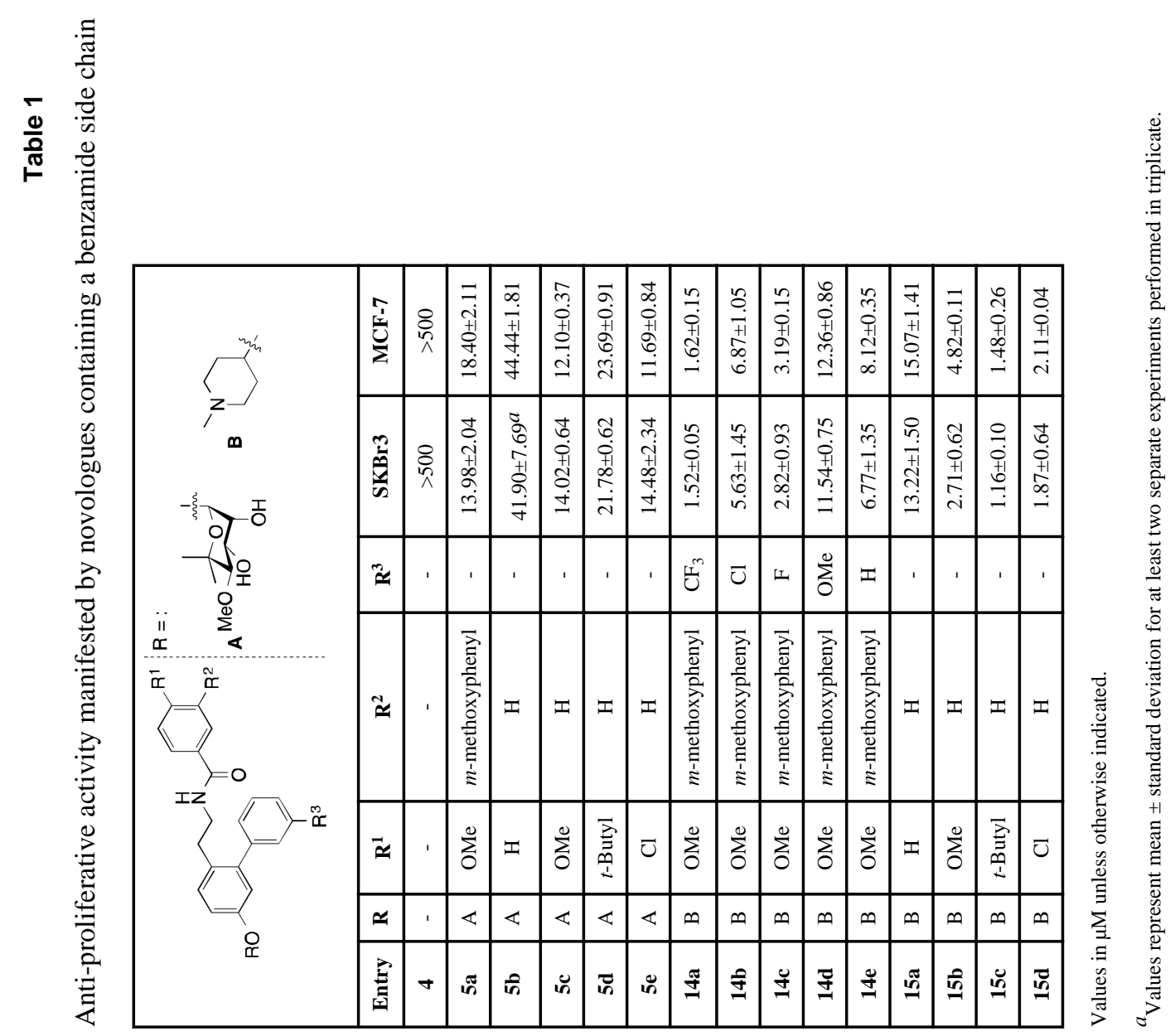

Bioorg Med Chem Lett. Author manuscript; available in PMC 2015 August 01. 


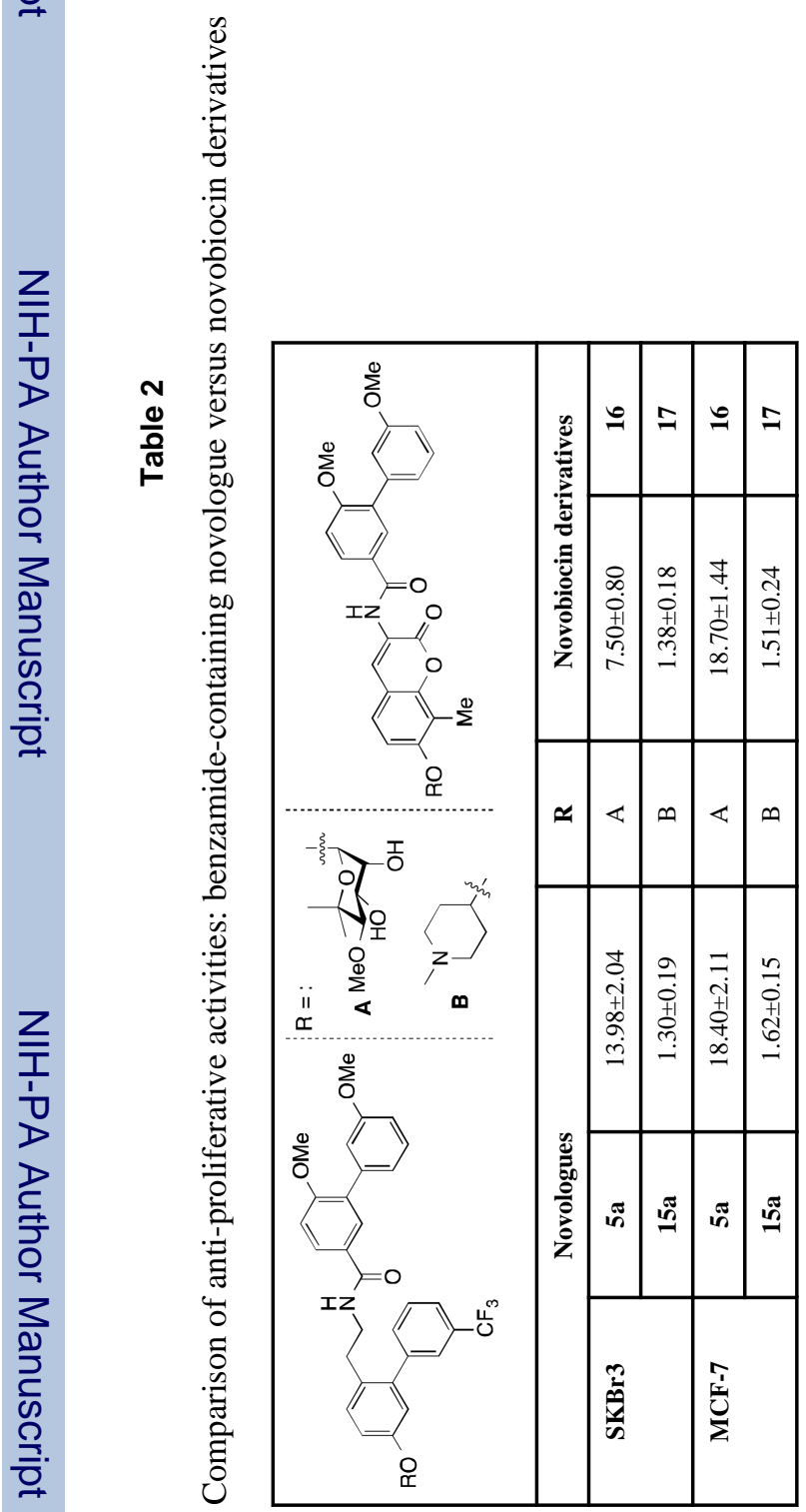

Bioorg Med Chem Lett. Author manuscript; available in PMC 2015 August 01. 